NEWTON'S DARKNESS

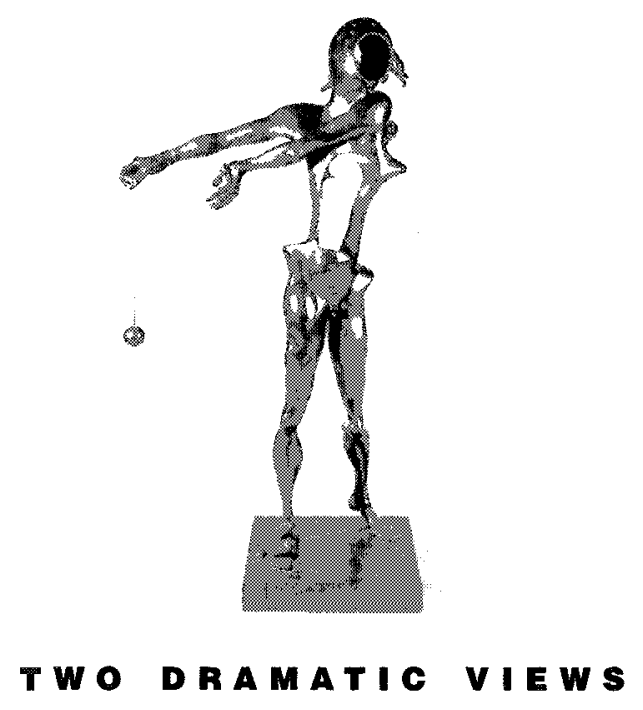


This page is intentionally left blank 


\section{NEWTON'S DARKNESS}

\section{TWO DRAMATIC VIEWS}

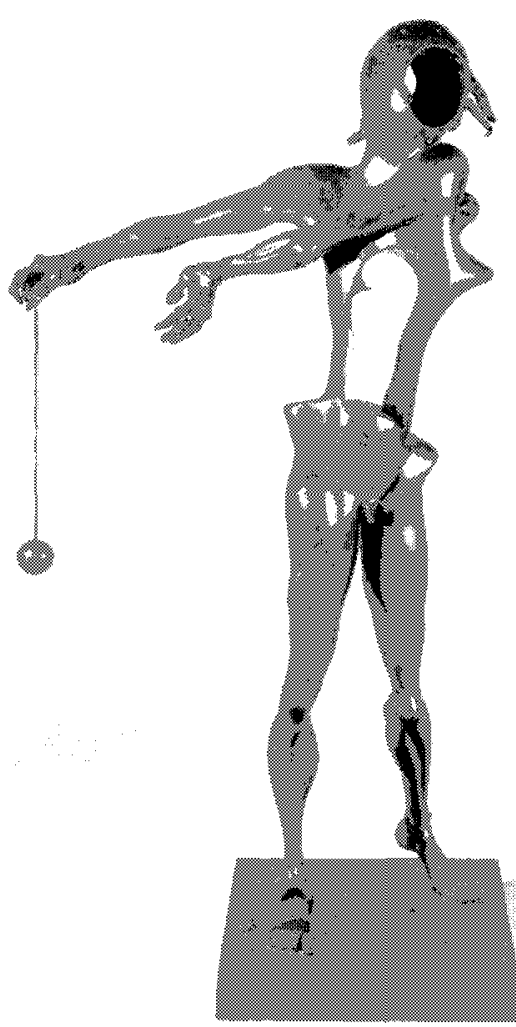

\section{Carl Djerassi}

Probessor of Chemistry, Stanford University www dierassicom

\section{David Pinner}

Visiting Associate Professor of Drama Colgate Universicy 


\section{Published by}

Imperial College Press

57 Shelton Street

Covent Garden

London WC2H 9HE

www.icpress.co.uk

\section{Distributed by}

World Scientific Publishing Co. Pte. Ltd.

5 Toh Tuck Link, Singapore 596224

USA office: Suite 202, 1060 Main Street, River Edge, NJ 07661

UK office: 57 Shelton Street, Covent Garden, London WC2H 9HE

www.worldscientific.com

\section{British Library Cataloguing-in-Publication Data}

A catalogue record for this book is available from the British Library.

\section{NEWTON'S DARKNESS \\ Two Dramatic Views}

Copyright $\odot 2003$ by Carl Djerassi and David Pinner

All rights reserved.

These plays are fully protected by copyright and any reading or performance of any kind whatsoever must be cleared with the copyright agents beforehand: "Calculus" by Carl Djerassi (via djerassi@stanford.edu) or "Newton's Hooke" by David Pinner (via Info@SteinPlays.com).

The right of Carl Djerassi and David Pinner to be identified as Authors of this Work has been asserted by them in accordance with Sections 77 and 78 of the Copyright, Designs and Patents Act 1988.

ISBN $\quad 1-86094-389-6$

ISBN $\quad 1-86094-390-X(p b k)$

Desk Editor: Tjan Kwang Wei 


\section{Contents}

Introduction: Flawed Genius 1

First View: Two Principals 15

Newton's Hooke by David Pinner

Second View: Three Minions

107

Calculus (Newton's Whores) by Carl Djerassi

Authors' Biographical Sketches

179

Acknowledgments 